\title{
A Study on the Research-Oriented Teaching Courses Reform in Chinese Colleges and Universities
}

\author{
Xinying Shi, Zhaoming Xue, and Hong Zhang
}

\begin{abstract}
The research-oriented teaching, by diversified organizing forms such as investigation research, project research and design, etc. and different teaching methods including heuristic, exploratory, discussion and PBL -based mode, exactly complies with the requirements of the Ministry of Education of China for reform of education and teaching methods in colleges, and is the trend of teaching pattern reform of courses in Chinese high level colleges. This paper analyzes the development and dilemma of research-oriented teaching reform in Chinese universities, and proposes solutions to the situation.
\end{abstract}

Index Terms-Research-oriented teaching, curriculum, course mode reform, bottleneck.

\section{INTRODUCTION}

In order to change the traditional cramming teaching mode and promote actively the innovation and creation of the teachers' teaching methods, teaching contents, teaching means and the students' learning style in Chinese universities, it is proposed in the document Some Opinions on Improving Comprehensively Higher Education Quality Issued by the Ministry of Education of China [1] that all teachers should innovate education and teaching method, advocate to take a new heuristic, exploratory, discussion-based, participatory teaching mode, promote the interaction between research and teaching, transform timely scientific research results into teaching contents, open key laboratories and research bases to students, support undergraduates to participate in the activities of scientific research and take part in projects, labs, or research teams earlier, reform examination means, pay attention to testing the learning process and evaluating students' ability. To promote actively the research-oriented learning activities and develop the reform of research teaching mode, is a breakthrough of personnel training mode reform in higher education. It is of great significance for Chinese universities to cultivate high quality innovative talents who have creative consciousness and creative ability.

\section{DEFINITION AND CHARACTERS OF RESEARCH-ORIENTED TEACHING COURSE}

Research-based teaching is a kind of interactive teaching and learning practice. During the process of teaching, teachers try to create a situation and way similar to the

Manuscript received February 15, 2014; revised April 28, 2014. This article is supported by the major teaching research project of Anhui Province under Grant 2013zdjy032.

Xinying Shi, Zhaoming Xue, and Hong Zhang are with Anhui University, China (e-mail: sxy190@163.com). scientific research, and then guide students to study the issues related to the teaching contents. Students are required to explore, think and practice independently, and to absorb and apply knowledge to solve problems actively, to gain new experience and behave their personality characteristics, so to improve their various qualities and cultivate their creative ability and innovative spirit [2]. In another word, research-based teaching course is a special kind of course that a teacher utilizes theme activities, investigation and study, project research, project design and a variety of research-oriented teaching organization form, practices heuristic, exploratory, discussion-based, issue-oriented modes and many other kinds of teaching methods to train students to be good at finding and asking questions, to explore and solve the problems.

Research-based teaching curriculum emphasizes on promoting students' subjective ability, adheres to " choosing freely, inquiring independently and creating freely" [3] by students in the process of curriculum implementation. Through teaching in small-classes and using flexibly a variety of research-oriented teaching organization form, discussion-based teaching is combined with research-oriented learning. Research-oriented curriculum embodies advanced educational idea. This kind of teaching mode is beneficial for improving students' subjective consciousness, and stimulating students' interests in learning, and cultivating students' research and practice ability and innovative spirit, cooperation and developing consciousness. And it is helpful to promote the good interaction of teachers' scientific research and teaching effect.

\section{AN ANALYSis ON PRESENT SituAtion AND BACKGROUND OF RESEARCH-ORIENTED TEACHING MODE REFORM IN CHINESE COLLEGES}

Research-oriented study as a kind of teaching mode experienced theoretical and practical exploration in 1960s and 1970s, but it was not a truly course form until the 1990s, after that the research-oriented curriculum was carried out widely under the impetus of the government in universities and primary and secondary schools in the United States, Britain, Japan and the other countries. The research-oriented teaching mode reform is more successful in America than in other countries. The most effective and characteristic undergraduate education courses are seminars for freshmen of Harvard University and FOCUS of Duke University, which aim at cultivating freshmen's exploring spirit and inspire their desire to seek for new knowledge. These research projects are multidiscipline and extensive. This kind of course employs excellent teachers as lecturers and tutors, and is organized generally in small classes with no 
more than 15 students. In small- group seminars, teachers and students may communicate with each other thoroughly and the undergraduates may experience the interest of discovery [4].

With the development of higher education reform in the world, some Chinese high-level universities carried out one after another beneficial exploration and practice of research-oriented teaching mode reform, such as Peking University, Nanjing University, Fudan University, Yangzhou University, etc.

For example, in 2006, Peking University began offering research-oriented courses, and spicily designed some small classrooms for research-oriented courses. There are 27 such small classrooms in Peking University at present, which may be classified into two types, one for 15 students and the other for 30 students. In 2011, 15 round-table classrooms that hold 30 students were rebuilt to meet the need of teaching [5].

In Nanjing University, research-oriented courses for undergraduates are classified into two types: seminars for low grade students and research-oriented courses for middle or high grade students. The former aims at guiding students experience the process of scientific research and probe, and then understand preliminarily the meaning of scientific research; the latter is organized in such cases that teachers put forward several questions to create a scientific research and approach to cultivate students' research consciousness and ability. In 2009,62 seminars for freshmen opened in 15 departments or schools in Nanjing University [6], including Physics Department, School of Environment, School of News and Media, etc. Half of the lecturers were professors from academicians, national famous teachers, Changjiang Scholars, Excellent Youth. These courses mainly took interaction, exploratory teaching mode, encouraging students to form a team and cooperate, experience the general process of academic activities. There will be maximum 30 students for each class. In 2011, 149 research-oriented courses were offered in Nanjing University [7].

Up to 2011, totally 92 research-oriented courses were totally offered in Fudan University [8]. Small-class teaching mode was employed. In the spring semester of 2014, 30 seminars are offered to freshmen by the first-class famous teachers. Each class consists of 15 to 20 students, so more discussions are organized among teachers and students. This kind of small-scale teaching form stimulates effectively students' activity and interest in taking part in the lessons.

Since 2006, Yangzhou University launched the reform of research-oriented teaching. As the first step, some teachers who lectured research-based courses rather successfully were selected to perform open demonstration teaching. In 2011 , in order to push forward the reform of research-based teaching mode, 100 research-oriented courses were chosen to construct as teaching model courses [9].

After huge work of investigation and research, Anhui University took steps to carry out the undergraduate research teaching course reform in 2013.42 research-oriented courses are set up as teaching projects in two batches. Some have been offered for undergraduate, others are in preparation. We audited some courses at random in the classes, and gathered the feedbacks from students' answers for questionnaire. All information indicates that research-oriented courses can successfully motivate students' enthusiasm to participate in study and have very good effects, so they are widely accepted by students.

\section{BOTTLENECK PROBLEMS IN THE REFORM OF RESEARCH-ORIENTED COURSE TEACHING MODE IN CHINA}

Although some Chinese high-level universities have carried out actively significant exploration actively and tried research-oriented teaching mode reform, and have gained some successful experience, most of Chinese general colleges have not yet began the reform and practice of research-oriented teaching mode. This situation by large owes to the bottlenecks in the research-based teaching model reform in the colleges and universities, which are rather difficult to break through.

\section{A. Problems of Education and Teaching Ideas}

To integrate the newest scientific research methods with latest results into the teaching content is undoubtedly very beneficial for inspiring and cultivating students' scientific research consciousness and ability. It will promote the interaction between scientific research and teaching, and the combination of research and innovative talent training. Nowadays, the phenomenon that the administrative personnel stress scientific research more than teaching is rather prevailing in Chinese colleges and universities. Many Chinese colleges and universities take the scientific projects and research achievement as the most important competitive edge. At the same time, teachers' research ability is taken as the main basis of evaluation and promotion of their professional titles. On the other hand, the reform and innovation of undergraduate teaching is comparatively neglected, so the potency dimension of the research-oriented teaching curriculum reform is limited.

Teachers and teaching management in Chinese colleges and universities insist in the traditional education and teaching ideas and methods or means. They are not familiar with the research-oriented teaching concept, characteristics and teaching mode, so it is not easy, to some extent, for them to understand this point. They are not adaptive to it, so they do not want to spare effort in developing and preparing research-oriented teaching courses which employ new teaching method and mean. According to the investigation carried out by Teaching Affairs Office of Anhui University, some teachers have not yet made clear the research-based teaching ideas and methods, so their teaching contents and teaching means are the same as the traditional courses.

\section{B. Problems of Teaching Faculty}

Research-oriented course cares much about the cultivation of students' innovative spirit, scientific research consciousness and creative ability. Teachers are required to incorporate the latest academic scientific achievement and trends while guiding students to take part in their research projects and improving students' research experience. Some courses even require teachers to lecture in foreign languages. While setting up research courses for senior undergraduates, its cohesion to the graduate curriculum should be taken into 
consideration. This requires the teachers' teaching ability, scientific research level, international education background and related professional experience should be comparatively higher than the average. In Peking University, Nanjing University, Fudan University, etc. research-oriented courses are given by the academicians of Chinese Academy of Social Sciences and Chinese Academy of Engineering, national or provincial well-known experienced teachers. Under their tutoring, students may cultivate good study habit, grasp the academic frontier and strengthen their academic interests and passion, improve their self-study ability.

\section{Problems of Teaching Conditions}

Research-oriented course is expected to be provided in a small-class. The most appropriate situation for teachers and students is to sit around a table in a special small classroom. This requires a college to build or transform a number of classrooms, and to equip them with a complete set of multimedia teaching facilities. The enrollment expansion of undergraduates in Chinese colleges brings about large-scale class. Anhui University, for instance, there are totally 1,617 full-time teachers, 20,449 undergraduate students. In the 2012-2013 school years, 1938 courses were offered (See Table I). The classes under 30 students accounted for only $23.63 \%$, while the ratio of classes between 60-100 and $100-200$ were nearly $50 \%$. It is difficult to carry out research-oriented teaching in a big class. To popularize small-class research course teaching will no doubt make the limited college teachers and the classroom resources become a more serious problem.

TABLE I: ClASS SIZE RATIO OF PROFESSIONAL COURSES IN ANHUI UNIVERSITY IN 2012-2013 SCHOOL YEARS

\begin{tabular}{|l|l|l|}
\hline $\begin{array}{l}\text { Class size } \\
\text { (students) }\end{array}$ & Course number & Ratio $(\%)$ \\
\hline Under 15 & 38 & 1.96 \\
\hline $15-30$ & 420 & 21.67 \\
\hline $30-60$ & 519 & 26.78 \\
\hline $60-100$ & 744 & 38.39 \\
\hline $100-200$ & 208 & 10.74 \\
\hline Over 200 & 9 & 0.46 \\
\hline Total & 1938 & 100 \\
\hline
\end{tabular}

\section{Problems of Quality Evaluation for Research-Oriented Teaching Courses}

In Chinese colleges and universities, the assessment of undergraduate courses is mainly based on the final examination scores. The daily scoring means is rather single, and accounts for a low ratio in the student's course grade. In Anhui University, for example, the student's course grade usually consists of daily score and final exam score, the former accounts for $30 \%$, while the latter for $70 \%$. The daily score is graded by class attendance, papers, and experiment reports and so on, without assessment of investigation and research or project design which can embody a student's research ability. This assessing means only leads to a bad way that students will cram before the final exam rather than research-oriented self-study with creative and research consciousness at daily learning. In order to evaluate a research-oriented teaching course, great reform of the evaluation system and methods is required. Such actions as thesis writing, research, discussion and social survey, and other forms of cooperation should be taken. Evaluators should pay more attention to probe into students' research learning process rather than the result of teaching.

The bottlenecks mentioned above in the process of research-oriented teaching mode reform is the main cause which blocks the development of research-oriented teaching course in Chinese colleges. Finding solutions to these problems is the base and key for Chinese universities to push forward the research-oriented teaching mode reform and achieve expected result, and thereby improve the training quality of creative talents.

\section{HOW TO PROMOTE THE IMPLEMENTATION OF RESEARCH-ORIENTED COURSE}

\section{A. To Carry out Actively the Research on the Research-Oriented Teaching Curriculum Reform in Colleges and Universities in China and Other Countries}

To identify the definition and the connotation of research-based teaching course and its characteristics, will be helpful for providing theory basis for purposefully developing research-oriented teaching curriculum reform in high-level universities. At the same time, by comparison and thorough analysis of the present situation of the research-oriented teaching curriculum reform in high-level universities in China and other countries, we should analyze the factors such as faculty, teaching conditions, curriculum system and course contents, teaching methods and means, which restrict the research-oriented teaching mode reform of a high-level university. Based on this research, countermeasures may be put forward.

\section{B. To Enhance the Cultivating of Research-Oriented Teaching Faculty}

Firstly, select teachers who are good at teaching and scientific research as to serve as tutors of research-oriented courses, take measures to train them how to carry out the research-oriented teaching mode reform. Secondly, establish a set of incentive mechanism to encourage the teaching faculty to carry out the teaching reform, such as offering favorable treatment in the assessment of their workload and teaching effect or their professional titles. Anhui University funded 20,000 Yuan for every research-oriented course since 2013 to help teachers collect relevant resources or prepare details.

\section{To Strengthen the Construction of Teaching Conditions for Research-Oriented Courses}

For example, in order to implement actively small-class teaching, we have to overcome the shortage of the classroom resource. We can renovate or construct a number of small classrooms (for less than 15 students) with a round table, which is suitable for small-class research-oriented teaching. On the other hand, we can provide internet system for students so that they can study independently and communicate with teachers more conveniently. Anhui University has set up an integrated management platform of network teaching. It collects lots of wonderful free teaching resources of many education institutions at home and abroad, such as MIT OCW, national excellent courses and other teaching resources from partner universities and over 200 
network course resources offered by the faculty of Anhui University. Thus, collecting efficiently worldwide useful resources and sharing broadly via the network platform is realized to a certain extent. Teachers may upload videos, teaching outlines, teaching plans, courseware, exercise databases, examination databases, teaching reference recourses etc, and communicate with students and answer questions online. The network platform can meet the students' demands of research-oriented learning and is a useful way to improve the teaching effect of research-based courses.

\section{To Set up a Set of thorough Research-Oriented Curriculum System}

We should optimize the curriculum design and its proportion of research-oriented teaching courses in the project of talent cultivation and the curriculum system, then try to build a set of research-oriented curriculum system which combines the following twains: undergraduate junior seminars with senior research-oriented teaching courses, research-oriented theory course with practice course, undergraduate scientific research training project and research course, etc. In Anhui University, we design "Undergraduate Sailing Course" and "Scientific Research Training Plan" for freshmen, set research-oriented teaching courses for senior students. These courses are given by selected experienced, knowledgeable teachers and aim at inspiring the students' creative thinking. Anhui University has been carrying out undergraduates scientific training projects and creating and enterprising training projects which require teachers and students to cooperate. Every project is funded with 10,000 or 20,000 Yuan. Teachers promote students' scientific ability by guiding students to review literatures, translate materials, carry out social investigation, do experiments, and analyze databases. In 2011, 92 undergraduate research training projects were set up, 185 students joined them and 84 academic papers were published ( 2 were recorded by SCI, 5 by EI, 8 by CSCD), 11 kinds of invention were applied for patented products. This is undoubtedly a remarkable result of research-oriented teaching mode reform. We should solve the problem of how to link perfectly the undergraduate senior research-oriented teaching courses with graduate courses. Research-oriented teaching courses focus on training students' scientific research consciousness and academic ability, so it should be considered in the design of research-oriented courses for senior undergraduates that some students prefer to continue their education and do some scientific research, for purpose of effective connection between relevant courses.

\section{E. To Establish a Scientific and Reasonable, Flexible and Changeable Quality Evaluation System for Research-Oriented Teaching Courses}

The teaching mode of research-based course is different from the traditional teaching mode, so the quality evaluation standards should change accordingly. Traditional course focuses on the effects of teaching, which is usually by means of summative judgment such as test paper, thesis, homework, etc. A teacher who undertakes a research-oriented course will encourage students to carry out research activities. He will stimulate students to study autonomously, to solve some problems and to discuss them with his team members. Through this kind of training, students will promote their inquiry and create consciousness and spirit. Comparatively, the assessment of a research-oriented course cares more about its teaching process. So, evaluating the teacher's teaching ability and the effect of students' study should focus more on the process [10]. It requires us to reform the existing evaluation system and to build a set of evaluation system to evaluate students' academic performance and teachers' teaching merit which aims at the characteristics of research-based teaching courses. This evaluation system should be flexible, scientific and reasonable. It will achieve this standard that the two-way evaluation between teachers and students is the main means, evaluations by colleagues or students and by oneself being complementary. This evaluation system will emphasize the evaluation of the teaching process between teachers and students.

\section{CONCLUSION}

Research-based teaching curriculum reform is a systematic project. In order to push forward the reform, the school leaders should change education concept. At the top of their developing design, an overall plan for cultivating innovative talents should be taken into consideration. All the teachers and students, teaching management faculty also should change education philosophy. Those departments for teacher training, teaching management, student work, education for graduate student, international cooperation and communications, and logistics management are supposed to work closely for the implementation of the research-oriented teaching mode reform, so as to form a smoothly and efficiently running integrated system and mechanism under one concept for research-based teaching curriculum reform.

\section{REFERENCES}

[1] The Ministry of Education of The people's Republic of China. (2012) Some Opinions on Improving Comprehensively Higher Education Quality Issued by the Ministry of Education of China (Higher Education. [Online]. 4.4 Available: http://www.moe.edu.cn/publicfiles/business/htmlfiles/moe/s7056/201 301/146673.html

[2] X. H. Chen, "Connotation, assessment and management of the research-oriented teaching in colleges and universities," Higher Education and Economy, vol. 3, pp. 7-11, September, 2008.

[3] W. G. Wu, "Malpractice of traditional courses and the era significance of research-oriented teaching," Education Exploration, vol. 12, pp. 40-41, December 2002.

[4] X. Z. Zeng, "Experience and enlightenment of research-oriented teaching reform in American universities," Education and Vocation, vol. 14, pp. 100-101, May 2013.

[5] Y. J. Sun and X. D. Lu, "Small-scale class research-oriented teaching: The core of undergraduate elite education - Taken Peking University as an example," Chinese College Education, vol. 8, pp. 16-19, August 2012.

[6] R. C. Chen and N. Xuan, "Nanjing University forge freshmen seminars teaching in small classes no more than 30 people," Chinese Education Newspaper, 2009.

[7] Ten Great Event of 2011 Undergraduate Education. Nanjing University Newspaper. [Online]. Available: http://xiaobao.nju.edu.cn/showarticle.php?articleid=12818.

[8] 2011 Undergraduate Education Quality Report of Fudan University. [Online]. Available: http://news.fudan.edu.cn/announce/?announceid $=409$.

[9] X. Y. Hu, Selected Compilation of the Research-oriented Course Teaching Cases of Yangzhou University, Nanjing: Jiangsu Education Press, 2012. 
[10] X. H. Wang, "A study of constructing curriculum evaluation system of research teaching in colleges and universities," Higher Science Education, vol. 21, pp. 91-95, April, 2012.

Xinying Shi was born in Huaibei City, Anhui Province, China in 1980. In 2005, she graduated as a master from History Department, Anhui University. Now she is working as an assistant research fellow in the Teaching Affairs Office in Anhui University, Hefei, China. Her research interest focuses on higher education management.

Zhaoming Xue was born in Lujiang County, Anhui Province, China in 1962. In 2007, he got a doctor degree from University of Science and
Technology of China. Now he is Director of Teaching Affairs Office, Anhui University. His main research field is functional complexes and higher education management.

Hong Zhang was born in Hefei City, Anhui Province, China in 1964. In 2001, she received a master degree in economics. Now she is the deputy director of Teaching Affairs Office, Anhui University. Her research interest focuses on tourist economy and higher education management. 